\title{
Study on the Construction of Yanbian Port in Heilongjiang Province Based on "Longjiang Silk Road Belt"
}

\author{
Nan YAN \\ Harbin University of Commerce, Harbin, China \\ 83566986@qq.com
}

Keywords: Heilongjiang Province, Yanbian Port, Economic Cooperation.

\begin{abstract}
Longjiang Silk Road" construction is the implementation of the strategy of "taking all road along the way", it provides important support and new economic growth pole, to promote the revitalization of the old industrial base in Heilongjiang Province and economic development. By analyzing the status quo of the border in Heilongjiang Province, the corresponding countermeasures are put forward to improve the opening degree of the open ports along the border in Heilongjiang Province and to play the role of the bridgehead along the border opening ports in Russia and Northeast Asia.
\end{abstract}

\section{Introduction}

Comrade Xi Jinping presented the historical conception of the "Silk Road Economic Belt" and "The Silk Road of the 21st Century" (referred to as "one belt and one road"), and this great idea became the new situation in China and opened to the outside in the new normal state a major strategic choice. Longjiang Luhai Silk Road Economic Zone (referred to as "Longjiang Silk Road Belt") is an innovative implementation of the "one way" strategy. After the outbreak of the Ukrainian crisis in 2014, Russia under the sanctions of western countries, Russia has experienced economic damage, so accelerate the development of the Far East, expand economic cooperation with the Asia-Pacific countries to become Russia's inevitable choice to restore economic development. In this context, deepening Sino-Russian economic and trade cooperation will promote the political stability and economic development of the whole region of Asia and Eastern Europe to a certain extent. Heilongjiang Province, as the key province of economic and trade cooperation with Russia, has continued to increase for many years. Therefore, the construction of "Longjiang Silk Road Belt" and the deepening of the Russian economic and trade cooperation are in the long-term interests of China and Russia.

\section{Analysis on the Present Situation of Yanbian Port in Heilongjiang Province}

Since the reform and opening up, with the gradual development of Sino-Russian economic and trade cooperation and border tourism, Heilongjiang Province was allowed to open up a class of foreign ports, from the original one to 25, Among them, the water port, including Harbin, Jiamusi, Huachuan, Suibin, Fujin, with the river, Fuyuan, Raohe, Luobei, Jiayin, Sun grams, Sun Wu, Heihe, Huma, Mohe, The port has Dongning, Suifenhe, Mishan, Hulin 4 ports, air ports are Harbin, Qiqihar, Mudanjiang, Jiamusi, the railway port, including Suifenhe railway station, and Harbin inland port. Of the 25 open ports mentioned above, 17 of them are open ports in Heilongjiang Province bordering on Russia. Heilongjiang trade in Russia accounted for $24.4 \%$ of the total trade value of Russia in the same period in 2015, which is the largest province of China's trade with Russia.

\section{Analysis of the Current Situation of Suifenhe Port}

Suifenhe port is the main line along the Silk Road Economic Zone of Longjiang Land and Sea, and the unique geographical advantage has promoted the development of Suifenhe's trade and investment in Russia. The development of trade at Suifenhe port is driven by trade, tourism promotion trade, both Complement each other, more comprehensive to improve the level of economic and trade cooperation with Russia, to create a bridge of economic and trade cooperation with Russia 
demonstration area. In addition, Sui Bo will be held, greatly promote the development of Heilongjiang Province, Russia's economic and trade, commodity circulation and personnel exchanges. In 2015, Suifenhe trade volume to Russia reached 1.66 billion US dollars, down 51.3\%, accounting for $47.2 \%$ of total foreign trade. Suifenhe advocated trade to promote tourism, tourism to promote trade, to improve the level of economic and trade cooperation with Russia, to build economic and trade cooperation with Russia bridge demonstration area. From the 2007-2015 in Table 1 that Suifenhe changes in the scale of trade with Russia, in addition to the decline in trade volume in 2015, the Suifenhe port import and export volume and trade with Russia is increasing rapidly every year, the scale of trade in Russia is constantly expanding trend, and Suifenhe port trade with Russia accounted for more than $40 \%$ of total foreign trade.

Table 1 2010 2015 Suifenhe port to the Russian trade scale Unit: million dollars

\begin{tabular}{|l|l|l|l|}
\hline Year & Trade volume & Trade volume to Russa & proportion(\%) \\
\hline 2007 & 464000 & 382000 & 82.3 \\
\hline 2008 & 582000 & 354000 & 60.8 \\
\hline 2009 & 350900 & 188000 & 53.6 \\
\hline 2010 & 605000 & 265000 & 43.8 \\
\hline 2011 & 700000 & 318000 & 45.4 \\
\hline 2012 & 852000 & 408000 & 47.9 \\
\hline 2013 & 834000 & 401000 & 48.1 \\
\hline 2014 & 759000 & 342000 & 45.1 \\
\hline 2015 & 352000 & 166000 & 47.2 \\
\hline
\end{tabular}

Data sources: According to 2007 2015 “Heilongjiang Business Yearbook” .

Suifenhe port of Russia trade is still under development, but its development efforts are weakening. This is mainly because the Suifenhe port location is unreasonable, so that other ports of its goods were diverted, leading to decreased competitiveness. At present, most Suifenhe enterprises only act as transporters and sales intermediaries in Russian trade, rely too much on the goods and markets of the Mainland and Russia, and do not give full play to the advantages of Suifenhe in terms of location, transportation, natural resources and policies, Characteristics of the advantages of industry, slowed down the construction and development of Suifenhe port speed. At the same time, Suifenhe City industrial layout deformity, weak agricultural base, low degree of industrialization, Suifenhe third industry in the absence of the primary industry and the second industry with strong support, the vast majority of trade, tourism, hotels and other traditional services, High gold content of the modern service industry, it is difficult to sustained and healthy development.

\section{Analysis of the Current Situation of Tongjiang Port}

Tongjiang port is the Longjiang Luhai Silk Road economic belt construction along the main line, with Jiang location, and Russia following the Ningschiaoya port only separated by a river, at the same time, the establishment of Tongjiang railway bridge will be connected to China The Northeast Railway Network and the Russian Siberian Railway Network, become China's third Russian railway transport channel, which is a new Asia-Europe transport channel. Tongjiang Port is the main line of Longjiang Luhai Silk Road economic belt construction. The same location is located in the northeastern part of Heilongjiang Province. It is located on the right bank of the Songhua River and Heilongjiang confluence in the northeastern part of Heilongjiang Province. Tongjiang is the largest port of water transport in Heilongjiang Province, the second largest port border trade. The establishment of the Tongjiang railway bridge will be connected to China's northeast railway network and the Russian Siberian railway network, becoming the third of China's Russian railway transport channel, is a new Asia-Europe transport channel. Tongjiang port is divided into east and west two operating areas, the port annual handling capacity of 4.6 million tons, the daily passenger inspection capacity of 2,000 people or more. The traffic system of the port is in all directions, with perfect water transport, road and rail transport network. The construction of the ice tank of the floating tank makes it easy to 
transport the goods between the same river and the following Ningshengye for 5 minutes, and realize the four seasons of the real meaning of the same port.

\section{Analysis of Heihe Port}

The Heihe port is the only relative city on the border line between China and Russia, and the Heihe port is the earliest border between China and Russia to carry out border trade and border trade, Of the important port, the Heihe in the Russian trade has a clear geographical advantage. Heihe port imports from Russia mainly for energy products and agricultural and sideline products, mainly for the export of electrical and mechanical products, clothing and agricultural and sideline products, in recent years, car exports began to emerge, but still in the initial stage. The overall view of the Heihe port on the Russian import and export commodity structure is relatively simple and most of the low value-added resource products and agricultural products, which also reflects the Heihe area industrial base is weak, difficult to support the status of industrial products exports. In 2015, the total import and export volume of 790 million US dollars of Heihe port, down 55.5\%. imports \$ 330 million, down 39.8\%; exports 460 million US dollars, down 70.1\%.

Table 2 2010 2015 Trade Scale of Heihe Port to Russia ～Unit: million dollars

\begin{tabular}{|l|l|l|l|l|}
\hline Year & Trade volume to Russa & proportion & Trade volume & Trade proportion to Russa \\
\hline 2007 & 129311 & - & 236494 & 54.67 \\
\hline 2008 & 180002 & 39.2 & 290179 & 62.05 \\
\hline 2009 & 54133 & -69.9 & 188739 & 28.68 \\
\hline 2010 & 53133 & -1.8 & 285511 & 18.60 \\
\hline 2011 & 138147 & 160.0 & 328388 & 42.07 \\
\hline 2012 & 192202 & 39.1 & 380644 & 50.49 \\
\hline 2013 & 217381 & 13.1 & 419375 & 51.83 \\
\hline 2014 & 123511 & -39.7 & 178094 & 68.32 \\
\hline 2015 & 58255 & -55.5 & 79146 & 72.64 \\
\hline
\end{tabular}

Data sources: Statistical Communique of Heihe City National Economic and Social Development.

\section{Analysis of Fuyuan Port}

Fuxuan port is located in the Wusuli River, Heilongjiang intersection of the triangle, in May 1992 to become a class of ports, officially launched in February 1993, is the most eastern port of China. Fuyuan port for the natural deep-water port, the terminal can also berth 33 000-ton barge, Fuyuan port infrastructure and ancillary facilities can basically meet the current cargo needs, with inspection units office building 3280 square meters, on-site joint inspection hall 2560 square meters, the annual cargo throughput of about 10 million tons. In 2014, Fuyuan County, the import and export volume of 783 million US dollars, an increase of 26.36\%; which exports 710 million US dollars, imports amounted to 0.73 billion US dollars.

After several years of development and construction, Fuyuan port service functions are maturing, the port inspection departments are complete, the port area construction with a large scale. Fuyuan port in the customs clearance on the implementation of 24-hour reservation system, Fuyuan port is export-oriented port, export trade accounted for about $90 \%$ of total imports and exports. In the import and export varieties, the main imports of wood, waste materials; exports mainly clothing shoes and hats, light industrial products, hardware appliances, building materials, agricultural machinery, food, fruits and vegetables. As of the end of 2015, Fuyuan Port has accumulated 2.25 million inbound and outbound tourists, 1.45 million tons of import and export goods, 54,000 inbound and outbound ships, and $\$ 6.2$ billion in foreign trade. 


\section{Problems in the Development of Port in Heilongjiang Province (Heading 3).}

Although the border construction of Heilongjiang Province has begun to take shape, but because of its border port location is remote, border infrastructure construction needs to be improved, the government support is not enough, making the border along the Heilongjiang Province, the following problems.

\section{Lack of Perfect Supporting Industry System}

Opening the border cross-border economic cooperation zone not only need to develop a major foreign cooperative industries, but also need to support the establishment of financial services, business services, exhibition economy, warehousing and logistics industry system. Lacking of open ports along the border in Heilongjiang Province and foreign cooperative industries supporting the industrial system, seriously restricts the effective development of cross-border economic cooperation between China and Russia. For example, the bank service system along the border area is lagging behind. The exchange of cash in the Russian and Chinese currencies is mainly based on the exchange of money, which poses a serious threat to the security of funds in cross-border economic cooperation. Suifenhe industrial layout deformity, weak agricultural base, low degree of industrialization, Suifenhe third industry in the lack of first industry, "the second industry with strong support, the vast majority of trade" tourism "hotel and other traditional services, the lack of gold content High modern service industry, it is difficult to sustained and healthy development. Secondly, the lack of a better warehouse logistics industry system, cross-border international express business less and delivery range is not broad enough, which seriously hindered the rapid development of cross-border economic cooperation between China and Russia.

\section{Lack of Perfect Supporting Industry System}

China and Russia have deep differences in regional cooperation and understanding of the differences, highlighting the Chinese side of the port opening and operation of a positive attitude, the Russian side of this cold. According to the border port officials, due to the Russian Far East sparsely populated, spending power is limited, many ports in Heilongjiang Province corresponds to the Russian side is not developed areas, the Russian side of the opening of the port is not too urgent demand, enthusiasm is not high. It is understood that the Russian federal government of its exports of resources to strictly control the goods, review, fees are numerous, but also to a certain extent, restricts the enthusiasm of local governments and Chinese transactions. China's focus on the strategic partnership between the two countries continue to deepen and improve, focusing on the long-term development of cooperation, from a macro point of view, is to better adapt to the complex and ever-changing international situation in the world of mutual trust, Mutual support; from a micro perspective, it is considered to be expected to better promote economic development between the two sides, driving the rapid and steady growth of local economy. Russia is to protect the normal operation of the national economy, Russia had a lot of export energy, in the process of distribution of benefits, due to the Russian local authorities at a disadvantage.

\section{The Role of Suifenhe Free Trade Zone is not Significant}

In many ports, Suifenhe is the most successful development, from import and export cargo volume, passenger traffic and other indicators of inspection, are the first in Heilongjiang Province. However, according to the survey found that Suifenhe its development space is limited, especially the serious shortage of industrial land, and restricts the economic and social development and opening up. Comprehensive bonded area can only be approved 1.8 square kilometers, is the smallest area of the comprehensive bonded area. Many projects because the land to promote the slow pace, or even unable to achieve the Heilongjiang Province, “export processing, import scratch landing” strategy.

Suifenhe port of Russia trade is still under development, but its development efforts are weakening. This is mainly because the Suifenhe port location is unreasonable, so that other ports of its goods were diverted, leading to decreased competitiveness. At present, most Suifenhe enterprises only act as transporters and sales intermediaries in Russian trade, rely too much on the goods and markets of the 
Mainland and Russia, and do not give full play to the advantages of Suifenhe in the "traffic" natural resources "policy, nor the self Characteristics of the advantages of industry, slowed down the construction and development of Suifenhe port speed.

\section{Countermeasures}

Heilongjiang Province is located in the northern border of the motherland, the Russian economic radiation area of more than 400 million square kilometers, and resource enrichment known outside the Baikal Krai, Amur border, the development of the Russian trade with "one to two states" unique geographical and resources Advantage. Learn from the successful experience of advanced ports, to strengthen the construction of ports in Heilongjiang Province, and actively carry out trade with Russia, for our region to speed up economic restructuring, change the mode of economic development, promote economic development.

\section{Speed up the Construction Process along the Border Ports}

Accelerate the construction process along the border of Heilongjiang can promote the development of Yanbian economy in Heilongjiang Province, and fully implement the "Longjiang Silk Road" strategy implementation. For Heilongjiang Province, it is necessary to actively join the other developed areas of the joint participation in the Russian Far East regional cooperation, take the joint development of the road. Through extensive attracting domestic and Hong Kong, Macao and Taiwan developed areas of large enterprises, large groups, the use of their funds, technology, management advantages to address the cooperation encountered in the funding and technical problems. In this case, they also want to find familiar with the Russian Far East strategic partners, together with overseas energy, raw materials and other investment projects. It is to adapt to this need, Heilongjiang Province put forward the "inside the outside cited" big article, the introduction of strategic investors, polymerization inland provinces and cities and Hong Kong, Macao and other areas of the power to jointly promote economic and trade cooperation in the Far East.

\section{Strengthen Cultural Exchanges between China and Russia}

At present, China is Russia's second largest tourist source country, Russia has become China's third largest tourist source country. Tourism industry is Sino-Russian economic and trade cooperation in the emerging industry, can greatly promote the cultural exchanges between the two peoples. Heilongjiang Province actively promote the innovation of Russian trade, and promote the development of cross-border e-commerce to Russia, making the value of tourism trade to enhance the value. In addition, Heilongjiang Province should pay attention to the construction of tourism infrastructure services for Chinese and foreign tourists to provide more quality tourism reception environment, to enhance the port of Heilongjiang Province, Russia tourism brand effect, speed up the escalation of cooperation in tourism in Russia.

\section{Adjust the Economic Development Structure of Heilongjiang Province}

At present, our district is in a critical period of economic transformation and strategic transfer, and it is also the historical opportunity for the future and development. Heilongjiang Province, the normal port customs clearance, the domestic and international trade environment will change, will drive the economic structure and industrial structure of the major adjustments, the great way of economic development will help Heilongjiang Province to play the international and domestic "two markets, two Resources, "the complementary advantages of the development of foreign trade processing and production enterprises to introduce and develop. Which will help to increase the local fiscal revenue, solve the employment of labor, speed up urban construction, stimulate local economic growth, realize the benefits of forestry transformation after the transformation of the land, To promote the region to achieve better and faster economic development. 


\section{To Implement the “One Way along the Way” Strategic Planning}

Bilateral government should strengthen mutual trust and exchange, the Heilongjiang provincial government should actively implement the "one way all the way" strategic initiative to create "Longjiang Silk Road" for the economic and trade cooperation in Heilongjiang Province to provide policy support and material basis. "Longjiang Silk Road” mainly relying on Heilongjiang along the railway, Sui Man railway, Dalian to Tongjiang railway three railway lines and the Russian Siberian railway, to integrate land and sea two Silk Road strategic advantages, is conducive to driving the Heilongjiang Provincial border economic development, thus promoting the overall economic level of Heilongjiang Province to improve. Russia is the "along the way" strategy of the main along the country, to implement the "area along the way" strategy can promote economic and trade cooperation with Russia's rapid development.

\section{Acknowledgement}

This research was financially supported by social science project of Heilongjiang province Education Department(12542067)and Special projects of Heilongjiang province philosophy and social science study(16JLD01)Innovation and entrepreneurship training project for college students of Harbin University of Commerce(201610240042)

\section{References}

[1] DONG Hong-li. Study on Restricting Factors of Urban Economic Development in China's Northeast Border to Russian Port [J]. Reform and Strategy .2016, (1): 142-147

[2] Tian li, Yan nan. Study on the Construction of Russian Border Port in Heilongjiang Province [J]. Commercial Economics .2016 (8): 7 9

[3] Zhao Longzhu. Study on the Development of Economic and Trade Cooperation between Heilongjiang and Russia's Border Port - Taking Suifenhe Port as an Example. [J] 2015, (15): 109-110

[4] Ma Youjun. Research on the Strategy of Promoting the Opening of Russia in Heilongjiang Province [J]. Siberian Studies. 2012, (2) : 22-28

[5] Li Jingyu, Feng Xiaochen. There are the main functional status of Suifenhe City in the docking of border trade between China and Russia [J]. Russia Central Asia Eastern European Market. 2010, (1): 26-35

[6] Bull Kasahara. Brazil and China: partners or competitors, Centre for Development and the Environment.[J].2011, (4): 21-23 